\title{
Brief Report: Rapid clinical recovery from Critical COVID-19 with Respiratory Failure in a lung transplant patient treated with intravenous Vasoactive Intestinal Peptide.
}

Jihad Georges Youssef, MD ${ }^{1}$

Faisal Zahiruddin, D.O. ${ }^{2}$

Mukhtar Al-Saadi, M.D. ${ }^{2}$

Simon Yau, M.D. ${ }^{3}$

Ahmad Goodarzi, M.D. ${ }^{3}$

Howard J. Huang, M.D. ${ }^{3}$

Jonathan C. Javitt, MD, MPH ${ }^{4,5}$

\section{Author Affiliations:}

1. Houston Methodist Pulmonary Transplant Center, Houston Methodist Research Institute, Houston Methodist Hospital, Houston, Texas, USA

2. Department of Academic Pulmonology, Houston Methodist Hospital, Houston, Texas

3. Houston Methodist Pulmonary Transplant Center, Houston Methodist Research Institute, Houston Methodist Hospital, Houston, Texas, USA

4. NeuroRx, Inc. Wilmington, DE

5. Johns Hopkins University, Baltimore, MD

\section{Keywords}

Vasoactive Intestinal Peptide, VIP, SARS-CoV-2, COVID-19, Acute Respiratory Distress Syndrome, ARDS, Acute Lung Injury, ALI, surfactant, Alveolar Type II

Correspondence to: jiavitt@neurorxpharma.com

Disclosure: Author JCJ is employed by a pharmaceutical company that is currently conducting clinical trials of RLF100 in patients with COVID-19 and has a financial interest in the outcome of those clinical trials. Author JGY has received funding as an investigator for RLF-100 through his institution.

Summary: RLF-100 (Aviptadil), a synthetic form of Vasoactive Intestinal Peptide (VIP) is shown to block replication of the SARS-CoV-2 virus and has been granted Fast Track Designation by the US FDA for the treatment of Critical COVID-19 with Respiratory Failure. We describe the clinical course of the first patient treated with this investigational medication in an open label manner -- a 54 year old patient suffering antibody-mediated rejection of his double lung transplant who contracted COVID-19 with respiratory failure refractory to all currently available therapies. He received three infusions of RLF-100 under an FDA-approved emergency use IND. Within 24 hours of the third infusion, substantial improvement in oxygen saturation and radiographic improvement in characteristic COVID-19 pneumonitis was noted. He was discharged from intensive care at that point and scheduled for discharge to home at 1 week on room air. Despite an intervening hospitalization for trauma, he remains alive and free of respiratory failure at 28 days post treatment.

\section{Background}

RLF-100 (Aviptadil), a synthetic form of human Vasoactive Intestinal Peptide (VIP) is shown to block replication of the SARS-CoV-2 virus and has been awarded FDA Fast Track Designation for the treatment of Critical COVID-19 with Respiratory Failure and has entered clinical trials in the United States and internationally. Since its discovery in 1970 by Said and Mutt ${ }^{1}$ VIP has been shown to protect the lung against a broad array of caustic, immune, and infectious injuries ${ }^{2,3,45}$ through its binding to the $\mathrm{VPAC}_{1}$ receptor of the Alveolar Type II cell. This is the same cell to which the SARS-CoV-2 virus binds via the ACE2 receptor ${ }^{6}$. VIP has previously demonstrated effectiveness in the treatment of ARDS related to sepsis ${ }^{7}$, arcoid $^{8}$, and pulmonary hypertension ${ }^{9},{ }^{10}$.

Concurrent with the award of Fast Track designation, the US FDA requested that the sponsor make RLF-100 available under emergency use IND. We report rapid and unexpected radiographic and clinical improvement in a 54 year old man with PCR+ Critical COVID-19 in the setting of antibody mediated rejection (AMR) and 
immunosuppressive therapy following double lung transplantation. Because of this co-morbid condition, the patient did not meet the enrollment criteria for NCT04311697, and was offered open label access to RLF-100 under an emergency use IND approved by the US FDA on a named-patient basis under the NeuroRx, Inc. expanded access program (www.clinicaltrials.gov NCT04453839).

\section{Clinical Report}

One year prior to presentation, the patient underwent a double lung transplant secondary to rheumatoid arthritisrelated interstitial lung disease and pulmonary hypertension. A week prior to presentation, he was treated for subclinical AMR with plasmapheresis, intravenous immunoglobulin and belatacept. 2 days later, he presented to the emergency room with headache fever of 103 and productive cough. His nasopharyngeal swab resulted positive for COVID; he received supportive inpatient care, remained stable without increase in $\mathrm{O}_{2}$ requirement, and was discharged home 3 days later.

After several days, he returned to the emergency room with worsening shortness of breath, fever and hypoxemia. His oxygen requirement continued to increase and was admitted to the intensive care unit for further care. Respiratory failure was evident with $\mathrm{SaO}_{2} 90 \%$ on high flow nasal $\mathrm{O}_{2} 30 \mathrm{~L} / \mathrm{min}$ and $\mathrm{FiO} 250 \%$. Patient received Tocilizumab for signs of cytokine release syndrome (CRS) without apparent benefit. Ferritin level was $1189 \mathrm{ng} / \mathrm{ml}$, interleukin-6 $126 \mathrm{pg} / \mathrm{mL} \mathrm{LDH} 447 \mathrm{U} / \mathrm{L}$ and CRP level was $20.07 \mathrm{mg} / \mathrm{dL}$. Awake prone therapy was not tolerated and was associated with worsening dypsnea. He was not a candidate for Remdesivir due to chronic kidney disease. Convalescent plasma was not available. Patient also received anticoagulation.

Intravenous Aviptadil was offered to the patient and following his agreement Institutional IRB and FDA emergency authorization IND were obtained. He received 312 hour infusions of intravenous RLF-100 (Aviptadil) at ascending doses of 50/100/150 $\mathrm{pmol} / \mathrm{kg} / \mathrm{hr}$. This treatment was associated with progressive improvement in blood oxygenation and radiologic appearance of pneumonitis on chest X-Ray and chest CT (figure 1). Neither the patient nor the clinical staff identified any adverse effects of treatment.

\begin{tabular}{|c|c|c|}
\hline & Before Infusion & $\begin{array}{l}\text { 24- hours post 3rd } \\
\text { infusion }\end{array}$ \\
\hline \multicolumn{3}{|c|}{ Portable Chest X-Ray } \\
\hline \multicolumn{3}{|l|}{ Scout CT } \\
\hline \multicolumn{3}{|l|}{ Chest CT } \\
\hline $\mathrm{PaO2}: \mathrm{FiO} 2$ & 146 & 285.19 \\
\hline $\mathrm{SaO} 2$ & 98 & 95 \\
\hline $\mathrm{FiO} 2$ & HFLNC 30 L/min, FiO2 50\% & $2 \mathrm{~L} / \mathrm{min}$ \\
\hline
\end{tabular}

Figure 1: Radiographic Appearance and blood oxygen saturation before and after treatment. Note the areas of 
consolidation and pneumonitis particularly in the right lung that are substantially resolved after treatment with concomitant increase in lung volume.

He was discharged from the ICU 24 hours following the third infusion and scheduled for discharge to home on room air 5 days following the $3^{\text {rd }}$ infusion. Despite an intervening hospital course for a retroperitoneal bleed following a fall, he remains alive, home, and free of respiratory failure at 28 days.

\section{Discussion}

To our knowledge, this is the first reported case of VIP being used to treat a patient with Critical COVID-19, with rapid clinical improvement in clinical parameters and radiographic features. Similar observations were recently reported in a patient with checkpoint inhibitor pneumonitis. ${ }^{11}$

The SARS-CoV-2 virus specifically attacks Alveolar Type II cells and does not enter the Type I pneumocyte. ${ }^{12}$ Loss of ATII cells reduces the lung's oxygenation capacity, particularly because the ATII cell is responsible for the production and recycling of surfactant in a addition to its other roles in supporting the pulmonary epithelium. ${ }^{6}$

VIP may have been particularly beneficial in the setting of AMR following lung transplantation based on prior reports that VIP preserves the function of lung allografts. ${ }^{13,14}$ VIP is a potent anti-cytokine in the lung that provides key defense against numerous forms of acute lung injury. Although named (or mis-named) for the tissue in which it was first isolated, VIP is produced by neuroendocrine cells throughout the body and by T-lymphocytes, Blymphocytes, and macrophages. VIP is highly localized in the lung but is a widely distributed immunomodulator with protective effects in heart, thyroid gland, kidney, immune system, urinary tract and genital organs. ${ }^{15}$

Early COVID-19 lung injury is characterized by a remarkable degree of hypoxia in the absence of overwhelming pneumonia, suggesting a primary injury to the pulmonary gas-exchange mechanism. VIP is the body's primary defense against cytokine injury in the lung and elsewhere. Unlike synthetic anti-cytokines, such as anti-IL6 drugs, VIP is shown to have a specific role in preserving surfactant production in the lung and in protecting type 2 alveolar cells. ${ }^{16,17,18}$ Accordingly, VIP and longer acting modifications of VIP have been proposed in the past as respiratory therapeutics ${ }^{19}$.

The SARS-CoV-2 virus is known to enter cells via binding to ACE2 receptors on the cell surface and those receptors are predominantly found on the Alveolar type II (ATII) cells. Moreover, VIP receptors are preferentially expressed on ATII cells and VIP is shown to prevent their apoptosis in models of lung injury. ${ }^{20}$ Li demonstrated in rat lung explants that VIP increased the incorporation of methyl-choline into phosphatidylcholine -- the major component of the pulmonary surfactants -- by enhancing the activity of the enzyme choline-phosphate cytidylyltransferase ${ }^{16}$. VIP upregulates C-Fos protein expression in cultured type II alveolar cells, which is instrumental in promoting synthesis of pulmonary surfactant phospholipids ${ }^{17}$ and induces surfactant protein A expression in ATII cells through activation of PKC/c-Fos pathway.

\section{Conclusion:}

The rapid clinical improvement seen in this first patient treated with intravenous RLF-100 (aviptadil), is consistent with the theory that VIP protects the ATII cell, blocks cytokine storm, and improves oxygenation in a lung that is under attack. This highly specific role of VIP in the lung may be key to combating the lethal effects of SARS-CoV-2 infection. A randomized prospective trial is underway, which will attempt to demonstrate that intravenous RLF-100 improves survival, oxygenation, and clinical course of Critical COVID-19 with respiratory failure. 
${ }^{1}$ Said SI, Mutt V. Potent peripheral and splanchnic vasodilator peptide from normal gut. Nature. 1970; 225: 863-864.

${ }^{2}$ Said SI. Vasoactive intestinal peptide in the lung. Ann NY Acad Sci 1988;527:450-464

${ }^{3}$ Said SI. VIP as a modulatory of lung inflammation and airway constriction Am Rev Respir Dis 1991;143:S22-S24.

${ }^{4}$ Said SI, Dickman KG. Pathways of inflammation and cell death in the lung: modulation by vasoactive intestinal peptide. Regul. Pept. 2000;93:21-29

${ }^{5}$ Javitt JC. Perspective: The potential role of vasoactive intestinal peptide in treating COVID-19. Authorea May 13, 2020 DOI: $10.22541 / \mathrm{au} .158940764 .42332418$

${ }^{6}$ Mason R. Pathogenesis of COVID-19 from a cell biologic perspective. Eur Respir J. April 9 Epub ahead of print. https://www.ncbi.nlm.nih.gov/pmc/articles/PMC7144II60/

${ }^{7}$ Youssef JG, Said S, Youssef G, Javitt MJ, Javitt JC. Vasoactive Intestinal Peptide in the treatment of Acute Respiratory Distress Syndrome. Lancet 2020, under review.

${ }^{8}$ Prasse A, Zissel G, Lützen N, Schupp J, Schmiedlin R, Gonzalez-Rey E, Rensing-Ehl A, Bacher G, Cavalli V, Bevec D, Delgado M, Müller-Quernheim J.. Inhaled vasoactive intestinal peptide exerts immunoregulatory effects in sarcoidosis. Am J Respir Crit Care Med. 2010;182:540-8

${ }^{9}$ Petkov V, Mosgoeller W, Ziesche R, Raderer M, Stiebellehner L, Vonbank K, Funk GC, Hamilton G, Novotny C, Burian B, Block LH. Vasoactive intestinal peptide as a new drug for treatment of primary pulmonary hypertension. J. Clin. Invest 2003;111:1339-1346.

${ }^{10}$ Leuchte HH, Baezner C, Baumgartner RA, et. al. Inhalation of vasoactive intestinal peptide in pulmonary hypertension. Eur Respir J 2008;32:1289-1294.

${ }^{11}$ Frye BC, Meiss F, von Bubnoff D, Zissel G, Muller-Quernheim J. Vasoactive intestinal peptide in checkpoint inhibitor-induced pneumonitis. N Engl J Med 2020;382:26

${ }^{12}$ Mossel EC, Wang J, Jeffers S, et al. SARS-CoV replicates in primary human alveolar type II cell cultures but not in type I-like cells. Virology 2008;372:127-135.

${ }_{13}$ Alessandrini, F., Thakkar, M., Foda, H.D., Said, S.I., Lodi, R., Pakbaz, H., and Schraufnagel, D.E. Vasoactive intestinal peptide enhances lung preservation. Transplantation 1993;56:964-973

${ }^{14}$ Pakbaz H, Berisha H, Sharaf H, Foda HD, Said SI. VIP enhances and nitric oxide synthase inhibitor reduces survival of rat lungs perfused ex vivo. Ann. N. Y. Acad. Sci. 1994;723:426-428

${ }^{15}$ Virgolini I, Kurtaran A, Raderer M, et. al. Vasoactive Intestinal Peptide Receptor Scintigraphy. J Nucl Med 1995:36(10):1732-1739

${ }^{16} \mathrm{Li}, \mathrm{L} .$, Luo, Z.Q., Zhou, et. al. Effect of vasoactive intestinal peptide on pulmonary surfactants phospholipid synthesis in lung explants. Acta Pharmacol. Sin. 2004;25:1652-1658

${ }^{17} \mathrm{Li} \mathrm{L}$, She H, Yue S, et. al. Role of C-Fos gene in vasoactive intestinal peptide promoted synthesis of pulmonary surfactant phospholipids. Regul Pept 2007;140(3):117-124

${ }^{18} \mathrm{Li}$ L, Hua S, Yue S, Luo Z, et. al., Vasoactive intestinal polypeptide induces surfactant protein A expression in ATII cells through activation of PKC/c-Fos pathway. Peptides 2010;31(11):2016-2051

${ }^{19}$ Mathioudakis AG, Chatzimavridou-Grigoriadou V, Evangelopoulou E, Mathioudakis GA. Vasoactive Intestinal Peptide Inhaled Agonists: Potential Role in Respiratory Therapeutics. Hippokratia 2013;17(1):12-16

${ }^{20}$ Onoue S, Ohmori Y, Endo K, Yamada S, Kimura R, Yajima T. Vasoactive intestinal peptide and pituitary adenylate cyclase-activating polypeptide attenuate the cigarette smoke extract-induced apoptotic death of rat alveolar L2 cells. Eur. J. Biochem. 2004;271: 1757-1767. 